ARTICLE

\title{
A Passion for the Sea: Human-Sea Interactions in Contemporary Caribbean Art
}

\author{
Hilda Lloréns \\ University of Rhode Island, US \\ hilda_Ilorens@uri.edu
}

This article reports on some of the ways in which the Caribbean contemporary artists Tony Capellán, Christopher Cozier, Scherezade Garcia, El Colectivo Shampoo, Jorge Zeno, Jennifer Allora and Guillermo Calzadilla, and Nadia Huggins deploy the semiotically rich imagery of the sea to comment on some of today's most pressing social concerns. The success of their artwork is the result of the fact that in visualizing local realities, they increasingly visualize the global condition. The Caribbean's history as a laboratory of the "modern" and the "globalized" has undoubtedly offered these artists a vantage point from which to launch their critical interventions.

Keywords: Caribbean; Contemporary Art; the Sea; Environmental Art; Relational Aesthetics; Global condition; Migration

This article focuses on how Caribbean visual artists produce "social and relational art" about human-sea interactions at the beginning of the twenty-first century (Bourriaud 113). In doing so, it engages in a closeup analysis of the ways in which particular Caribbean visual artists experience, engage and immerse themselves with/in the sea as a lifeworld terrain to produce semiotically rich imagery that render themes of historical and contemporary significance such as Diaspora, dislocation, travel, and undocumented migrations, liminality, waste, pollution and environmental degradation, U.S. military surveillance and intervention. Depicting the sea as an important feature and resource for island dwellers has a long history. And while the work of Caribbean writers on this topic has been amply analyzed, the present article contributes to the growing scholarly literature about the way in which Caribbean visual artists use and deploy the sea as the site in which the aesthetic, as well as socio-political narratives in the artwork, take place.

Contemporary Caribbean artists are both in dialogue with broader artistic trends and cultural debates. Yet, more importantly, they often intentionally challenge "classic" Western hegemonic artistic tenets by deploying and rendering their unique perspectives to contemporary art making and practice. The tension between the local and the global to which artists from so-called peripheral countries, such as the Caribbean islands, are subject, is crucial to understanding the complex ways in which their work is consumed and circulated. Artist Chris Cozier, whose work is discussed in this article, has written compellingly about this. As a Trinidadian artist, Cozier is keenly aware that in order for artists from so-called peripheral places/spaces to have broader circulation in "mainstream" White Euro-American art circuits, their work must somehow reflect "their realities" and thus, they remain tethered to the specificity of the local, a burden not experienced by White Euro-descended artists who are defined and naturalized as mainstream and whose concerns are rendered as globally relevant rather than as local(ized).

Yet, through their artwork the artists examined here testify to current socio-political issues that exist well beyond local, land-based national and geographic terrains. I am concerned with understanding the ways in which artists deploy the sea as a central geography or space on which the dramas of contemporary human life also unfold. Even as they differ from one another, the Caribbean-born artists examined here engage the sea as icon, medium and as lifeworld terrain. Their common conceptual preoccupation with the sea invites viewers to reconsider and redraw the boundaries of belonging. 
Their artwork reveals the sea as an intrinsic character, and at times a protagonist, in the imaginary of islanders' socio-political and cultural life. In their creations, they propose societies built on the backs of dislocated peoples whose sea-crossings are fundamental to the region's history. These artists engage with the sea as that great body from which islanders spill forth onto the land(s) (and not the other way around).

At least since the late 1970s Caribbean visual artists have increasingly addressed ecological themes in their artwork to comment on the negative anthropogenic impacts unleashed by human economic and social practices on island ecosystems (Wood 158-159). Wood aptly explains that the relationships between natureart-society in this region of the world are expressed through a process she calls geo-identity. She defines this term as the interconnection between physical space and its representations in social imaginaries and artistic poetics, and as such it is a critical mode of witnessing the realities of the ecosystem (Wood 160).

Some of the artworks discussed in this article have been featured in early 21st-century metropolitan museum exhibitions such as Island Thresholds: Contemporary Art from the Caribbean at the Peabody Essex Museum in 2005; Infinite Island: Contemporary Caribbean Art at the Brooklyn Museum in 2007; Caribbean Crossroads, a collaborative exhibit organized by El Museo del Barrio, the Queens Museum of Art, and the Studio Museum in Harlem in 2013; Caribbean: Crossroads of the World at the Pérez Art Museum in 2014; and in 2015 Poetics of Relation at the Pérez Art Museum in Miami. All attest to the vitality and significance of the region's artistic production.

These recent shows bolster Leon Wainwright's assertion that "complex stories of art unfolded as Caribbean artists have positioned themselves in networks of art practice throughout the Atlantic world" (1). As commodities, works of art-products that travel independently of their makers ${ }^{1}$-become incorporated within exhibitions and international art markets. Metropolitan museums charged with preserving cultural patrimony, educating and representing their publics, but also with entertaining their cosmopolitan consumer base occupy a place of intermediacy. The museum must satisfy elite educated metropolitan donors as well as attract socially excluded populations for whom the museum might be seen as a foreign and unwelcoming terrain. This location of intermediacy or what Clifford, citing Mary Louise Pratt, has called "contact zones" is charged with facilitating "cultural relations within the same state, region, or city" (204). It is notable that the artworks examined here have for the most- part been exhibited at metropolitan "ethnic" or minority museums. The metropolitan ethnic museum is indeed a "contact zone," sometimes in reverse, because their politicized mission seeks to respond to as well as point out for visitors "histories of exclusion and silencing" (Clifford 213-214; Ruffins; Walsh).

In their artwork visual artists challenge stereotypes of the Caribbean as a tropical paradise or utopia where people are indifferent to contemporary world events. They also challenge prevailing notions that their concerns and artistic production lag behind "contemporary" trends (Wainwright). Although twenty-first century Caribbean artists often reference the past, their art is of this time here and now. In other words, Caribbean artists are coeval with the contemporary world. A hurdle confronting the Caribbean artists exhibiting in metropolitan centers is mainstream viewers and prominent art critics, both of whom often view and review Caribbean artwork from a cultural evolutionist perspective. Wainwright offers one such example when he writes:

Holland Cotter, a notable reviewer of the Brooklyn Museum's Infinite Island: Cotemporary Caribbean Art (2007), wrote disparagingly that: "Multiculturalist terms like identity, hybridity and diversity may sound like words from a dead language in Chelsea [New York], but they are the lingua franca of the Brooklyn show." ... ultimately, Cotter took the view that striving to be "post- identity" should be the eventual and inescapable aim of all Caribbean artists wishing to compete with New York's lead. (8)

Yet, Cotter's devaluation is born out of mainstream ignorance about the Caribbean's importance in Atlantic history. His assessment unveils the erasure of the Caribbean and its people and their significant role in the making of European expansion and American modernity. Unfortunately, this essential misunderstanding is common in metropolitan assessments of Caribbean art. This results in critics' and viewers' inability to understand that a core issue, although not the only one, with which Caribbean contemporary artists grapple is

\footnotetext{
${ }^{1}$ The artwork is a mobile entity; it moves physically between places, and temporally through history. Its meanings change depending on its social context, location, and audience. As such, the works do not present a singular coherent identity but rather exist in manifold realities distributed through diverse spaces. These works of art function as spaces in which ideas and subjectivities are examined and reimagined. In them, the Caribbean is a site of constant change and infinite possibility. Tumelo Mosaka, Infinite Island: Contemporary Caribbean Art.
} 
precisely the multiplicity of people, indigenous and African, as well as those who arrived from all corners of the world, who came together under unequal conditions to make new social, political, and cultural worlds. Caribbean artists have long been at the artistic vanguard in grappling with conditions that have characterized their surroundings for hundreds of years and which are now increasingly mirrored around the globe. In the American hemisphere, there is now a long history of contemporary Black, Indigenous, Latinx, Asian, queer and feminist artists who have expanded normative notions of the performative and the conceptual through the use of irony and re-appropriation in order to make strident political commentaries that speak to the specificity of their realities yet, have universal resonance.

\section{Methods}

Here, I approach the artworks of a small number of prominent Caribbean artists from an anthropological perspective, examining their works critically and interpreting them contextually while offering an iconographic and iconological analysis. Some of the works of art are originally installations of multiple paintings or performances, but within the scope of this article, they have been flattened into images representing singular views of a broader picture that is the subject of Caribbean artists more generally. I bring these pictures into conversation with the wider socio-cultural and geo-political landscape and use the work of previous scholars in "thinking through" these images. I do this because in Lewis Hyde's words artists are "regularly honored as creators of culture," and I believe that they offer glimpses into the "cracks between language"-often seizing on cultural silences and contradictions, the unspeakable or barely known, or the disruptive and the grotesque or vulgar to make their marks (Hyde 260). Analyzing the critical role of the artist and her work opens a window through which to glimpse the very things "cultures are based on" (Hyde 260). Following Wilson Harris's notion that "...a philosophy of history may well lie buried in the arts of the imagination," Patricia Mohammed notes the lack of representational analyses of the interstices "of history and culture that are difficult to capture with cold, hard, logical facts" (Mohammed 9; Harris). And, although artistic representations mirror human social and political life in many ways, they do more than mirror, they also "act upon" viewers to "defamiliarize" or to make new again that which is naturalized (hooks). Citing Goodman, Mitchell reminds that "images are 'ways of worldmaking,' that produce new arrangements and perceptions of the world" (Mitchell 93; Goodman 1). Through their use of relational aesthetics, Christopher Cozier, Scherezade Garcia, Tony Capellán, Colectivo Shampoo, Jennifer Allora and Guillermo Calzadilla and Nadia Huggins, whose work I analyze here, invite viewers to co-construct meaning and/or to altogether reimagine the world anew.

In examining the socio-cultural concerns represented in these contemporary artworks, I focus on understanding ways in which artists unsettle outsiders', as well as insiders', views of the Caribbean as a region of insular entities detached from world events. What this "close-up" analysis reveals is that even as they comment on local and national issues, contemporary Caribbean artists emphasize the region's dynamic global interconnections aiming at "blurring borders" and questioning futile notions of insularity altogether.

\section{Positioning the Caribbean Visual Arts in History and Modernity}

Caribbean people have historically engaged in a multiplicity of sea-crossings. In the pre-colonial era, Amerindian intra-Caribbean voyages fostered social interaction across islands, an important feature in the region's social and political life (Curet and Hauser 7; Mol 176). This intra-island connectivity did not end with the eventual destruction of pre-colonial life, but the trans-Atlantic trade of enslaved Africans greatly impacted entrenched social organizations shifting the maritime routes and drawing new, and often dangerous, political boundaries. As Bonilla and Hantel suggest, the region is exemplified by a history of "...fractured, uneven, contested, and negotiated sovereignty..." "...best understood as a nonsovereign archipelago, where patterns of constrained and challenged sovereignty can be said to repeat themselves" (Benítez-Rojo 2; emphasis in original). Even when the analysis of national geo-politics produces fragmented histories, each island-nation is a part of a larger inter-connected whole. But a successful mapping of the Caribbean must incorporate the region's "maritime" and "aquatic" roots, routes, and politics or else it will remain landlocked and hopelessly incomplete (Bassi). In other words, the seascape must also figure as a key terrain in the mapping of lifeworlds.

In their artwork the Caribbean artists I analyze here deploy sovereignty as exercised beyond land and the physical landed territory of the nation-state. Sovereignty is lived and acted upon at sea as well as on land. The sea represents a source of freedom and of self-ownership, a no-man's land or commons where individuals are "free" to dream up future selves and possible lives; moreover, as a physical and real part of the natural world the sea is an unpredictable force. As a source of sublime experience the sea has the potential to "un-do" individuals and offers a confrontation with something greater than oneself. In this way, entering 
the sea is a "leap of faith" in which an individual's very humanity-and not only their nationality- is tested and where the possibility of renewal and re-birth stands as the reward. In their work, the artists under study propose that imaginings of what sovereignty means in the Caribbean must take into account the place of the sea in the lives of individuals and communities. Sovereignty with respect to individuals is the desire for freedom and thus transcends the nation state. In deciding to migrate out of a wish to travel or in a desperate attempt to escape economic, social, or political oppression a migrant enacts their sovereign will, even when it means that given the conditions of the voyage death is a certain outcome.

For some Caribbean residents-those who live their lives between two islands or who have relatives in multiple islands in the region- the sea is not isolating but is a connecting entity linking the islands and their peoples. I propose that the notion of the shared sea, with its "moving items and ideas," is a corrective to the "grounded" notions of insularity (D’Arcy 6). The St. Lucian poet and playwright Derek Walcott writes in his influential poem, "The Sea is History,"

Where are your monuments, your battles, martyrs? Where is your tribal memory? Sirs, in that grey vault. The Sea. The sea has locked them up. The sea is History. (364)

Walcott's capitalization of "History" signals what Édouard Glissant so eloquently explained: "History is a highly functional fantasy of the West, originating precisely at the time when it alone 'made' the history of the World" (64). In Walcott's poem, "that grey vault" is a shared physical entity that transcends localized national histories. The sea, a seemingly living entity with dynamic currents and flows, is an apt metaphor for the histories of the islands as well as the continents, their people, and the world. The sea emerges in this poem as the life-blood that binds and blurs the earth's terrestrial geography. For Caribbean people, the sea is a significant entity in each island's physical and imaginative landscape. But Walcott's focus on the sea as a cryptic place of untold depth and imaginings points to a productive intellectual vein through which regional and indeed global dynamics can be examined in the visual arts.

\section{Migration and Risk}

In this research I have been reminded that History, as a sweeping global narrative, has insolently disregarded the stories of the very people-the island's original inhabitants and the captives transported from the shores of Africa to the Americas-whose lives violently birthed modern History. As Toni Morrison aptly remarked, "modern life begins with slavery" (178). The sea thus emerges as a shared feature among Caribbean peoples. In fact, as shared "body" the sea and its maritime routes gave birth to what would become a centuries-long socio-economic commonality for "the islands": the plantation.

Writer and cultural critic Antonio Benítez-Rojo was one of the late twentieth century's most important exponents of the notion that the Caribbean can "also be regarded as a cultural sea without boundaries," (314) a conception he advocated again in a later essay appropriately titled "The 'New Atlantis'" (215-224). Colonial usurpation, the plantation, successive migrations, and hybridity or creolization shape the environmental, economic, socio-cultural, political, and historic facets that together constitute the Caribbean archipelago. However, at the beginning of the twenty-first century, other "repeating" features further transformed this Caribbean archipelago. The plantation economy was replaced by the tourism economy. Transnationalism, in which personal and political life takes place across two or more nation-states, is now a way of life for large numbers of Caribbean peoples (Basch et al.). And with advanced communication technologies, everyday practices of social life and interaction across borders and through the computer screen are a reality (not solely the purview of science fiction). At the beginning of the twenty-first century, human-technology engagement and hyper-connectivity have become central to the global condition. Inter-connectivity has new dimensions that radically challenge archaic notions of insularity.

It is within this context that the multifaceted Trinidadian artist Christopher Cozier "examines contemporary social issues" that "resonate across the world" (Ramirez 84). The Castaway (Figure 1), part of a larger work titled Tropical Night (2006-), asks, in the artist's words, "How do we define living in a site that was designed for others to play in?" (Laughlin). In an interview about Tropical Night Cozier remarked that the drawings comment on:

what one might call the burden of context. The burden of history. The burden of being from a place-it's tiresome to keep saying this, but even more tiresome that it's true-from a small, peripheral place where individual sensibility is trapped on all sides: by ideologies, by national "culture" narratives, by stereotypes-by that whole tangle of expectations about what it means to be an artist from and in the Caribbean. (Laughlin 2007) 


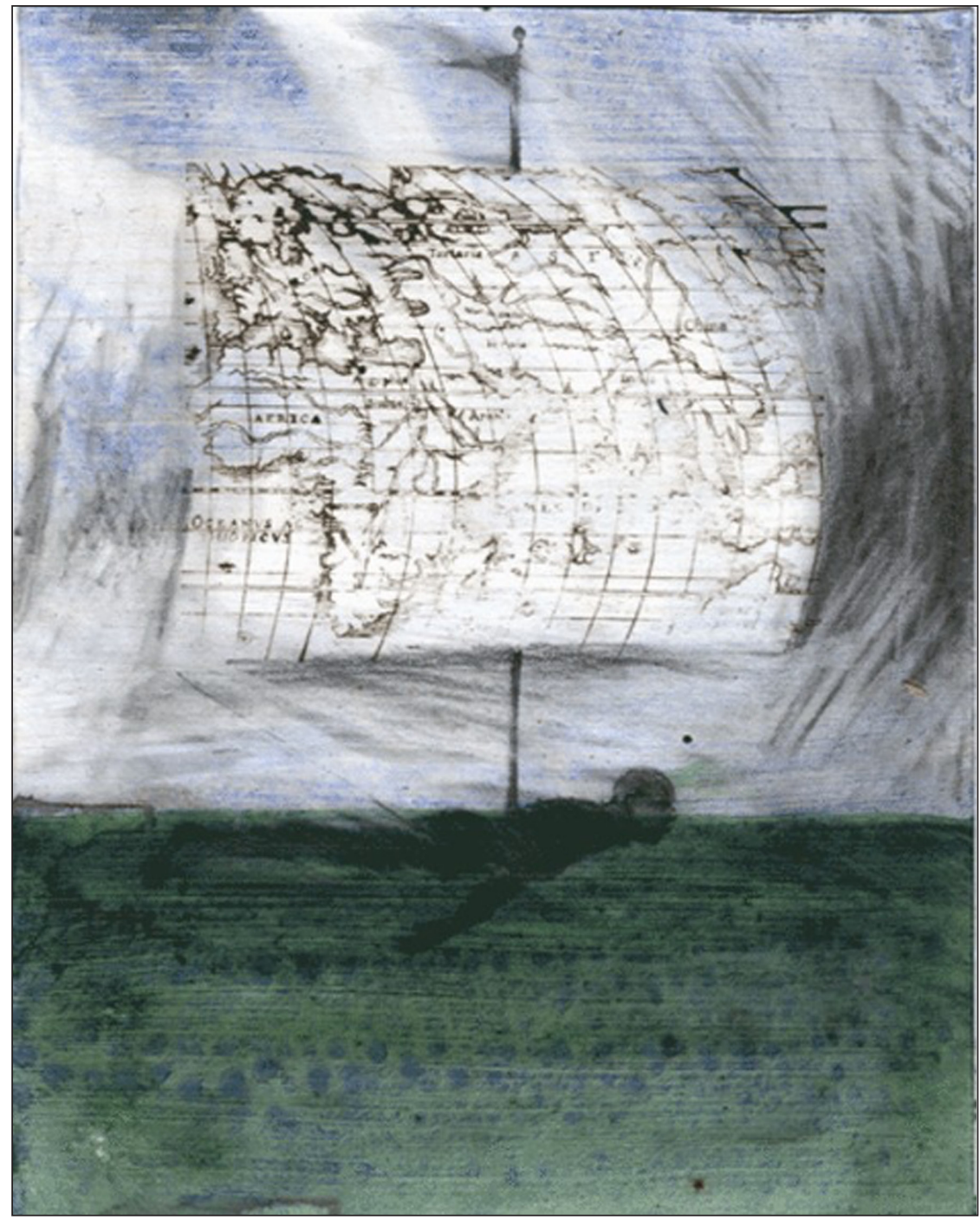

Figure 1: The Castaway from: Cozier, Christopher. 2006.

In that statement, one hears echoes of Caribbean writers such as Jamaica Kinkaid, Derek Walcott, C.L.R. James, and Edward Kamau Brathwaite. Cozier states that "[m]any of these islands were not supposed to be 'societies' to begin with, after the period of conquest and plunder. We were never supposed to be 'individuals' either" (Laughlin 2007). The "we" to whom Cozier refers to are the islanders, the descendants of the island's indigenous inhabitants and the former enslaved Africans, as well as the indentured servants brought from India and China to toil on the plantations. The Castaway is an image of a black man turned into a sailboat. The sail has been painfully staked to his back and he appears to be both floating in the sea and flying in the sky. The sail, which contains an antique world map, is a comment on the post-1492 modern condition in which the movement of people-some as chattel or labor, others as sovereigns in search of wealth, adventure and/or leisure-and goods, is a defining feature. The piece's title illuminates the liminal (Turner 47) sense of the Caribbean-also known as the "Inter-American Seas"-as a place betwixt and between the Old and the New Worlds. The Castaway is a lone sailor with the sail as a cross on his back. The sail hinting that movement, sail, and flight, are life conditions for the inhabitants of these, often themselves castaway, "small places."

In Cozier's painting the figure is forever shipwrecked but draws his life force from the elements, suggesting another narrative about the place of environmental forces in the lives of Afro-Caribbean people. The fecundity of the tropics and its fertile sandy soils birthed mercantile capitalism and eventually global modernity. While The Castaway poignantly evokes Bauman's assertions about "wasted lives," Cozier offers a hopeful glimmer of the ways in which "superfluous bodies," as agentic selves, decide to "stake a sail on their backs" to reach other worlds where they might be "re-born" as useful (not wasted) humans.

In Post-Nationalism Prefigured, anthropologist Charles V. Carnegie explains that "transnational modes of dwelling are not only a recent fad but have historical depth in a region such as the Caribbean" (Carnegie 65). Citing Orlando Patterson, he writes, "the Caribbean is one of the few cases in which migration has become 'a 
basic means of individual and societal survival'" (Carnegie 65; Patterson 106). Indeed, similar to almost every region of the world today, historically the Caribbean's defining characteristic is its multi-layered assemblage of peoples, histories, cultures, and traditions, a palimpsest predicated on its insertion into the global political economy. The multiple and complex migrations to and within the region that led to the creation of the new societies' cultural and economic arrangements led anthropologists such as Sydney Mintz, Eric Wolf, and Michel- Rolph Trouillot to argue that the Caribbean region has been modern "since its early incorporation in various North Atlantic empires" (Trouillot 228). The region's significance in the establishment of early global economic markets as well as the multicultural societies that developed there exemplifies Mintz, Wolf, and Trouillot's claims of a now centuries-old modern Caribbean.

The Caribbean's earliest citizens were aware of worlds-Africa, Europe, Asia, North and South Americathat existed beyond their shores. As the generations passed on and multiplied, the memories of previous lives in these worlds as well as the passage from the old into the new world receded into historical memory, often exemplified in mysterious objects, icons, symbols, and even words whose original meanings had been recast. Yet the cultural and artistic material created by members of each society (music, art, dance, festivals, food, religious, spiritual and linguistic practices) and the materials' symbolic content are laden with references to the past. Today, as Caribbean peoples continue the long tradition of migration, dislocation, and re-invention, symbolic cultural production also continues to grapple with past and present, near and far experiences. As Küchler and Melion have noted, "Images engender modes of recollection as much as they are determined by them" (7). The modern condition, inaugurated by seafarers-turned-merchants and colonialists, opened the way to voluntary and forced mass movement and displacement of people and goods across the globe; this movement continues unabated in our era. In 2015, a nameless and nationless ship serving as a temporary "home-land" to hundreds of Rohingya and Bangladeshi migrants dubbed "boatpeople" drifts from port to port along the Andaman Sea, unable to find a "nation" that would accept them. ${ }^{2}$ This was only one instance in a constant stream of catastrophic news and images, both still and moving, of African, Middle-Eastern, and Southeast Asian women, men, and children risking their lives in perilous sea crossings, hoping to find a better life in more "prosperous" nations. At the same time, national borders, both land-based and maritime, have become militarized zones where "illegal" or "alien" persons are aggressively prohibited leading to an array of desperate entry methods and dangerous smuggling networks (Chavez; Weber and Pickering; Márquez; Bauman).

Discussing modern biopolitics, Giorgio Agamben argues convincingly that at least since World War I, the birth-nation link that produces national and juridical- political citizenship (giving certain kinds of persons active rather than passive political rights to shape the nation-state) is unraveling. ${ }^{3}$ The refugee, composing a "significant part of humanity" numerically, "must be considered for what he is: nothing less than a limit concept that radically calls into question the fundamental categories of the nation-state" (78). Following this striking insight, consider that just as the refugee concept exposes the limits of certain persons' rights within the nation-state, entire nation-states are in themselves "refugee states" within global neoliberal modernity. Indeed, Agamben notes that "today's democratic-capitalist project of eliminating the poor classes through development not only reproduces within itself the people that it excluded but also transforms the entire population of the Third World into bare life" (101). In other words, the so-called Third World is itself peopled by those who have little or no active political rights on the world stage, the stage where decisions are made that reproduce their exclusion from global-financial citizenship.

Cozier's The Castaway reminds of the current conditions experienced by Haitians, Cubans, Dominicans, and other Caribbean islanders risking their lives at sea to enter the United States or its territory (variously known as boatpeople, botpippel, or balseros), and who have made front-page news on the American continent for the last 50 years (Martínez-San Miguel; Martínez; Paravisini-Gebert and Kelehan; Duany; Crichlow; Graziano). This global "migrant crisis," as it is often called, is a symptom of expanding global inequality. In the financial era, these dangerous sea crossings attest to the fact that inequality extends far beyond the basic human rights to food, water, shelter, and safety. Inequality encompasses all areas of life and death, even the elusive search for

\footnotetext{
${ }^{2}$ Interestingly, in 2008 Patri Friedman (grandson of Milton Friedman) and Peter Thiel founded the Seasteading Institute. This institute, whose board of trustees, advisors, and staff only has one female member, aimed to design and create the first floating city with "significant political autonomy by 2020." The goal of this group, once the floating city is established, is to serve as a "test-case experiment in governance" (www.seasteading.org/floating-city-project/). I assume this "experiment in governance" is part of the floating city's business model and/or novelty available to qualified consumers or to what is known in luxury market parlance as "high net-worth individuals." See also: See www.nytimes.com/2015/05/15/world/asia/burmese-rohingya-bangladeshi-migrantsandaman-sea.html and www.nytimes.com/2015/08/17/world/europe/turkey-greece-mediterranean-kos-bodrum-migrants-refugees.html?_r=0.

3 See Agamben, Giorgio. Homo Sacer: Sovereign Power and Bare Life. Stanford UP, 1998.
} 
a "better life" in a foreign nation, which is a stratified undertaking. The nationless are an increasingly large group, often depicted as a mass of rachitic brown bodies exposed to the elements-sun, wind, salt water, sand, earth-as they drift in the sea cramped with hundreds of others in inhumane and degrading conditions. The stream of images depicting "displaced" peoples confirms anthropologist Ulf Hannerz's observation that, "there are now various kinds of people for whom the [concept of] nation works less well" (385).

Another artist, Scherezade Garcia and the curator and writer Alana Lockward took on the compelling subject of undocumented migration in a performance titled "Salvation Action," which took place in the seaside village of Sabana de la Mar in the Dominican Republic in 2003. Sabana is an important point of departure for undocumented migrants leaving the Dominican Republic for Puerto Rico in the small fishing boats known as yolas. The word salvation in Garcia's title has multiple meanings. First, she questions the idea of salvation: "is the promise of a better life in a foreign land enough to risk one's life by crossing the Mona Strait in small, overcrowded fishing boats?" (Berg). During the performance, Garcia had a local seamstress fabricate pink life-jackets, which she then placed on men and children. Testimonies she had gathered about the dangerous migratory crossing inspired the motifs she drew on them. This sea passage, known for its giant waves, is one of the most dangerous in the Caribbean. Garcia also deploys the lifejacket in contradictory symbolism. Often absent from the boats Garcia's imagery encourages reflection on whether in fact life jackets serve as a source of safety, yet the pink color of the jackets symbolize feminine energy, evoking motherly protection over the wearer. Writing about Haitian artists who have rendered the tragic history of the botpippel, Paravisini-Gebert and Kelehan observe that "[a]s artists, they have also become memorialists, historians, witnesses who have brought to life on canvas a narrative that seems to many forgotten" (159). Through Salvation Action, Garcia and Lockward were similarly moved to memorialize and to document, but also to act. The work includes a video of the artists and others fabricating life jackets was a way to "take action" and to offer would-be migrants some human-made defense against the sea. Yet at the end of video, the viewer is confronted with an empty life jacket flapping in the waves; a lifejacket is no match against the unpredictable sea. The emptiness here might also point to the passage from citizenship-derived personhood to the invisibility brought on by the transition to undocumented non-personhood. The moment a Dominican citizen or national enters the sea he or she becomes an empty "vessel" onto which juridical labels such as illegal alien are mapped. The lifejacket signifies the migrant's evacuation into an abyss of unknowing entailed in the very act of migration itself.

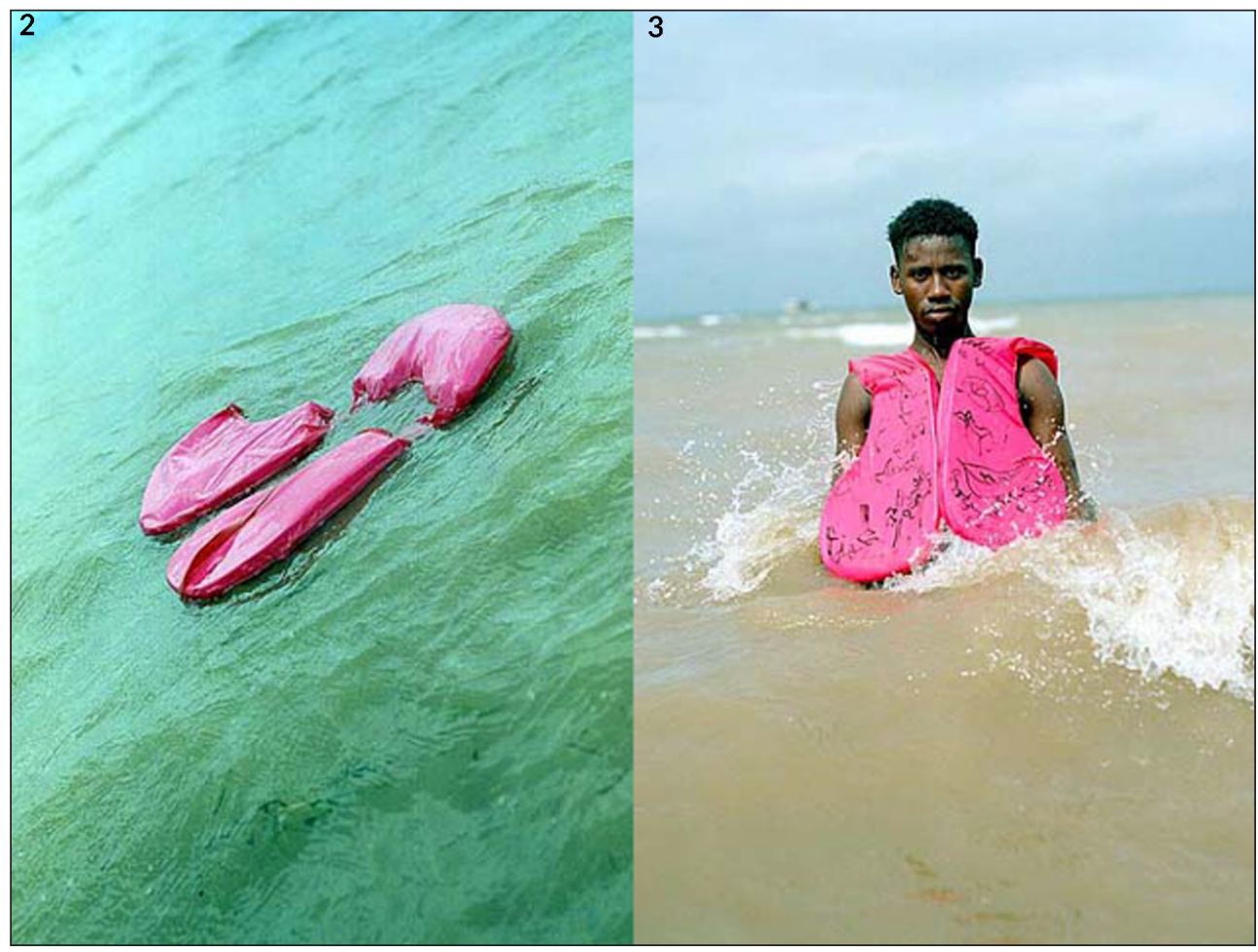

Figures 2 and 3: "Salvation Action" from: Garcia, Scherezade and Alana Lockward. 2003.

\footnotetext{
${ }^{4}$ See www.youtube.com/watch?v=0yTJ4QPr5II.
} 


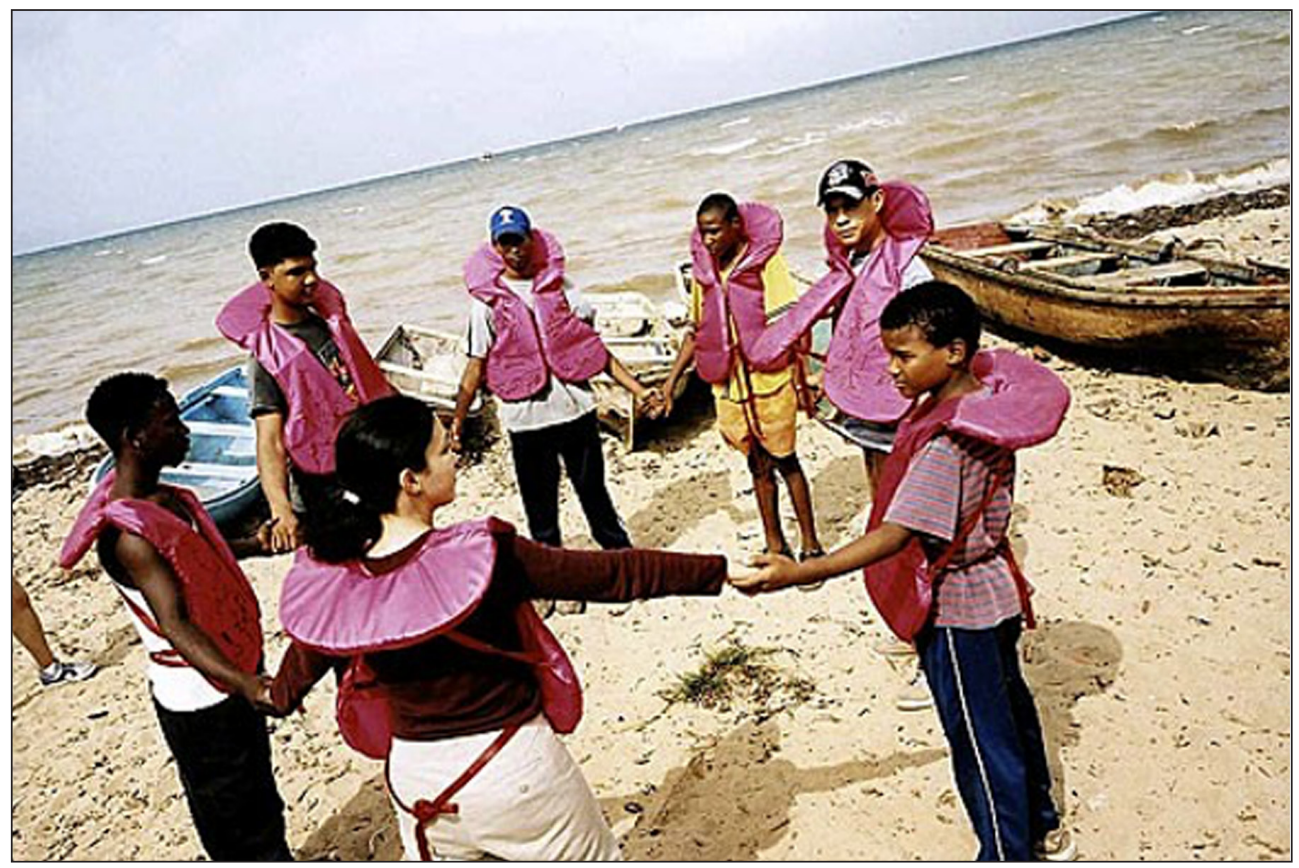

Figure 4: "Salvation Action" cont'd from: Garcia, Scherezade and Alana Lockward. 2003.

\section{Policing the Seas}

Island artists frequently comment on the sea as a passageway and as an escape route. Every year thousands of people from Cuba, Haiti, the Dominican Republic, and other islands attempt dangerous sea crossings searching for better lives in places perceived to be economically prosperous. In the nineteenth century, before U.S. involvement in the region, Puerto Ricans migrated by sea to the Dominican Republic in search of work (Duany). Motivated by political instability, Duany explains that "[l]arge-scale migration from the Dominican Republic to Puerto Rico took off after 1965" (189). In Undocumented Dominican Migration, Frank Graziano explains that "Many migrants [...] relate a quest for basic economic stability; the 'American Dream' is hardly on their minds. They are motivated more by a Dominican dream: the alleviation of the struggle for subsistence..." (14). Graziano adds that "migration is often a compensatory transnational means of subsistence: one supports one's family from abroad because there is no work at home" (15). In the Dominican Republic, thousands of people take to the sea each year on unsafe yolas hoping to reach Puerto Rico, a territory of the United States. ${ }^{5}$ They hope that once there, they will find employment and thus move from "superfluous" and "redundant" to "gainfully employed."

Lacking economic opportunities pushes them into dangerous and "illegal" journeys that too often end in tragedy. If a yola traveling from Samaná, Dominican Republic to Aguadilla, Puerto Rico capsizes in the Mona Passage, throwing its 70 migrants into the sea and no one lives to tell about it, does it make a sound? In the age of hightech surveillance, it is difficult to imagine that this morbid scenario occurs. Customs and Border Protection Dash 8 aircrafts, as well as Coast Guard cutters and helicopters routinely patrol the Mona Passage. As Graziano explains,

Many yolas are first detected by a Dash 8. This aircraft has two interfaced computer stations on board, one for radar on the left and one for digital imagery on the right ... After identifying a yola, Dash 8 stays on site to take photographs and video to track the yola's course" (185-186).

Thus, in the twenty-first century the images of Dominican nationals traveling by sea to Puerto Rico (a U.S. territory) often in rickety and overcrowded vessels are increasingly part of a juridical visual archive stored in the mainframe computers of the U.S. Custom and Border Protection section of the U.S. Homeland Security Department. The images that result from this "juridical seeing" become a significant legal aid for the U.S. immigration officers "in proving that migrants in international waters were heading for Puerto Rico" (Graziano 186).

Alongside this prosecutorial canon, another catalogue of images has emerged-what I call "Caribbean border art"-representing undocumented travel by sea. Oboler and Gónzalez explain that as a conceptual category, border art "emerged in the early 1980s with the growing militarization of the United States- Mexico

\footnotetext{
${ }^{5}$ A yola is a small wooden boat traditionally used for fishing in the Caribbean.
} 
international border" (209-213). I borrow this productive concept to purposely locate the Caribbean artists and the works discussed here as they confront and represent how islanders and Dominicans in particular relate to the maritime border between the Dominican Republic and the U.S. territory, Puerto Rico.

El Colectivo Shampoo, a Dominican multidisciplinary artistic collective whose core members include Angel Rosario, Maurice Sanchez, Mario Dávalos, and Jose Dolores Alfonseca, also take up travel from the Dominican Republic to Puerto Rico through the dangerous Mona Channel in their piece D'la Mona Plaza: The Waters Stop Here (2004).

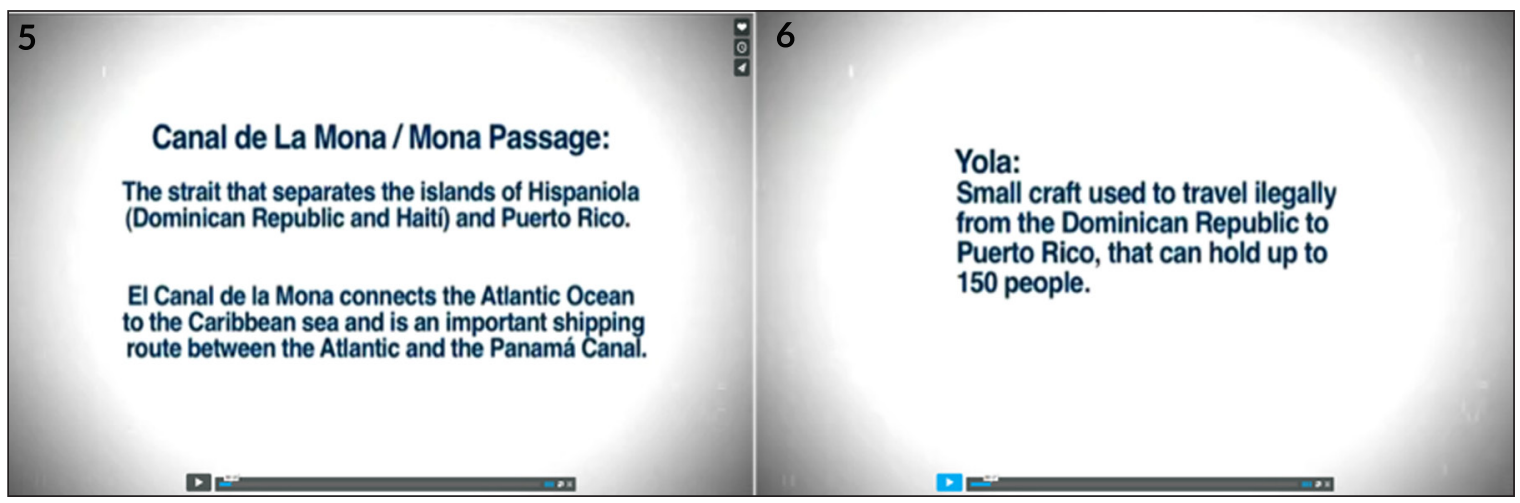

Figures 5 and 6: D'La Mona Passage (screen-shots) from: Colectivo Shampoo. 2004.

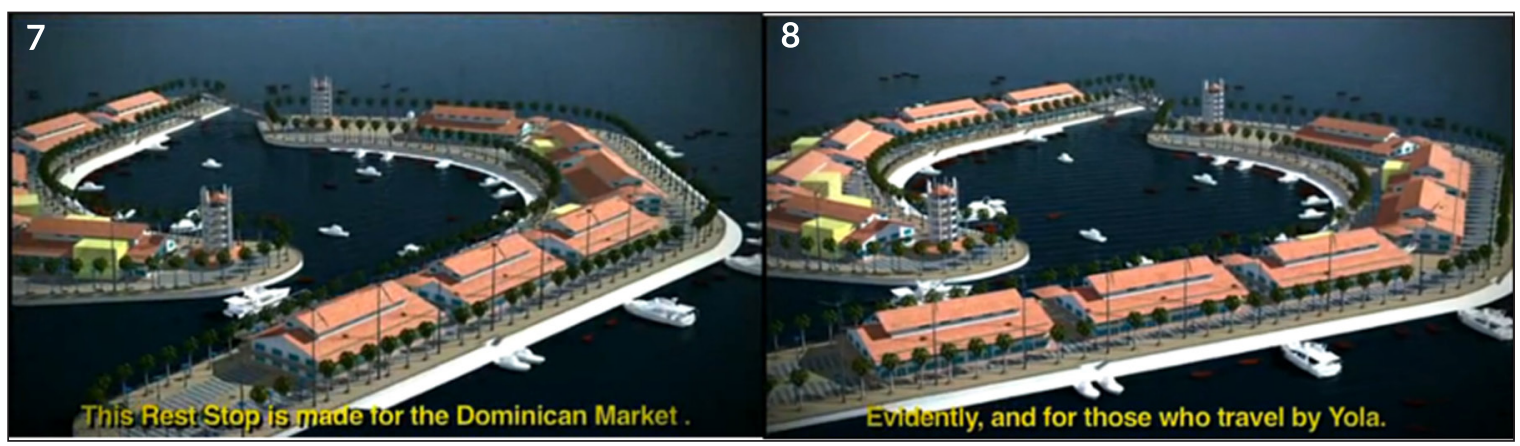

Figures 7 and 8: D'La Mona Passage (screen-shots) from: Colectivo Shampoo. 2004.

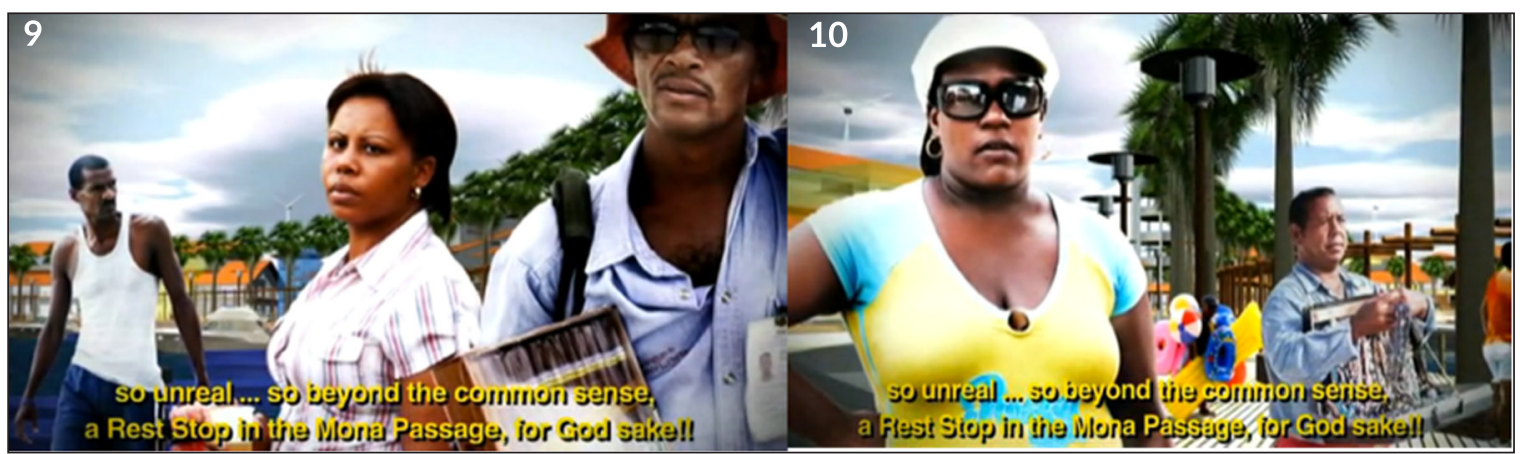

Figures 9 and 10: D'La Mona Passage (screen-shots) from: Colectivo Shampoo. 2004.

With it they propose a compelling sociocultural commentary on both the undocumented Dominican migration to Puerto Rico and the leisurely travel of Puerto Ricans to the Dominican Republic. ${ }^{6}$ El Colectivo Shampoo harnesses the power of irony by constructing an entire project that appropriates the tools and language from the very system they are critiquing. As a result, their multidisciplinary installations make powerful statements about inequality and race and the ways in which market forces exploit these salient social issues. The inequality between the two islands and their people's ability to move freely along the Mona

${ }^{6}$ See vimeo.com/39690174. 
Passage is thrown into stark relief. They also point out the real-world possibility that "the market" in the shape of predatory business people and real-estate developers often seize upon the misfortune of others, in this case on the unrelenting and dangerous path taken by undocumented would-be Dominican migrants to Puerto Rico through this stretch of ocean, as a way to fatten their wallets.

In a personal communication, Jose Subero, a Dominican architect who worked with the core members of El Colectivo Shampoo on aspects of this project, explained that to bring their art to the public, they created an advertisement for D'La Mona Plaza and placed it in local Dominican newspapers. The advertisements were placed in the classified sections of various newspapers marketing the sale of commercial spaces at the (fictitious) rest stop. The ad included a phone number that when called was answered by a recording in the voice of a Puerto Rican woman asking interested "would be" buyers to leave a message. This made it appear as if the "would be" builders of D' La Mona Plaza were based in Puerto Rico giving the concept an added air of credibility thereby underscoring the existing power dynamics and inequality. D'La Mona Plaza the fictitious rest stop in the Mona Passage would offer travelers a shopping mall, a food court, bathrooms with facilities for bathing, and medical facilities to "assist victims of shark bites." The daring advertisement was "picked up" by local Dominican news outlets engendering commentary from the astonished television hosts. Subero explained that through the advertisement the artists wanted to illustrate how local television news and variety shows often seize upon news, no matter how absurd the content, and report events without verifying the validity of the information (Subero 2015).

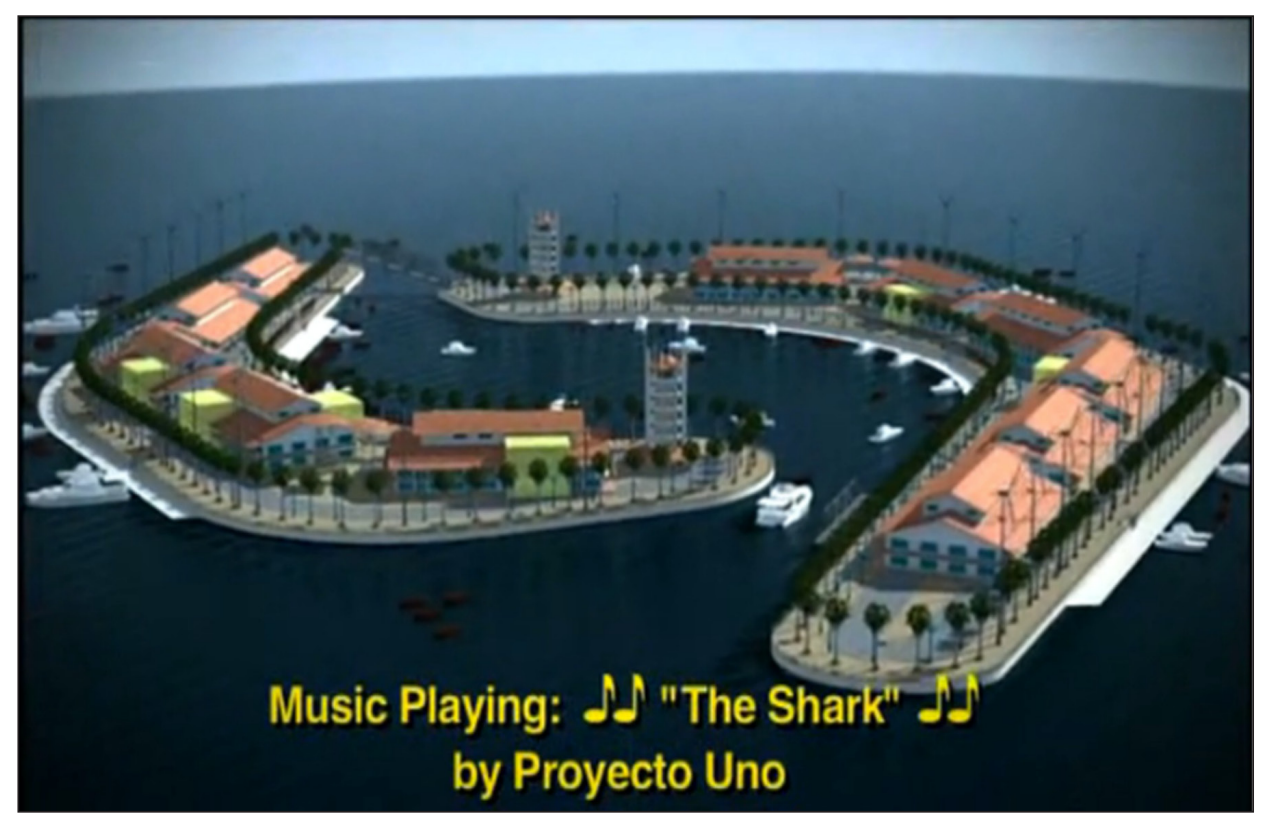

Figure 11: D'La Mona Passage (screen-shots) from: Colectivo Shampoo. 2004.

Combing snippets from the television news shows that mistakenly believed the artwork was a "real" plan to build a "plaza" for undocumented migrants, as well as the graphic architectural renderings of D'La Mona Plaza, El Colectivo Shampoo then created a video, which overlapped images of the "fake" renderings with the comments made by the astounded television personalities. Figures $\mathbf{5}$ and $\mathbf{6}$ depict the explanatory captions of the video's beginning. The dialog in Figures 7, 8, 9, and $\mathbf{1 0}$ are translations of the comments made in Spanish by the television hosts. In Figure 11 El Colectivo Shampoo, whose name is a word play on Dominican consumerism and the obsession with hair and grooming, smartly overlaps a merengue song by the group Proyecto Uno titled "El Tiburón" [The Shark] against the backdrop of the architectural rendering for the imaginary rest stop. The merengue song "El Tiburón" is not a commentary on the danger of the migratory crossing per se. It is about a married man who goes to a nightclub to meet women only to have the shark (another man) snitch on him, stealing the women who would have been his extra-marital affair. The tiburón is thus an opportunistic creature who takes advantage of other people to further his aims. It is a metaphor for predators both human and animal. On the one hand, it points out the predatory behavior of smugglers and others who take advantage of the migrants' plight; on the other, it reminds of the sharks trailing the yolas at sea in hopes of a meal. 


\title{
Waters to Freedom
}

Scherezade Garcia has continued to appropriate and transform objects such as the floating inner tube, used for both poolside leisure and as a vessel, to offer poignant commentary about the power differentials of migration and travel. In a recent exhibit at The Art Gallery at the College of Staten Island titled Aguas Libres/ Waters of Freedom (2015), Garcia dipped inner tubes in gold paint and stacked the tubes to construct a large sculpture titled Catedral/Cathedral (see Figures 12 and 13) that mimics a floating altar, evoking universal migration stories. Garcia explains:

\begin{abstract}
The inner tubes are attached together by electrical ties, sometimes in distress alluding to pain and suffering. This piece is pregnant with airport suitcase ID tags in different colors, referencing the diversity of origins on the journey in search of paradise, the land of opportunity. These airport tags are transformed by adding an all-inclusive "cinnamon" color to resemble the colors of the statue of liberty. This color is the result of mixing all colors therefore the action of mixing is inclusive. This universal altar is surrounded by water. I created a collection of silkscreen prints with images on water. This silkscreen installation is titled "The liquid highway." The images of water allude to the liquid road that migrants from all over the world had to cross to reach the new land of opportunity on their journey (2015).
\end{abstract}

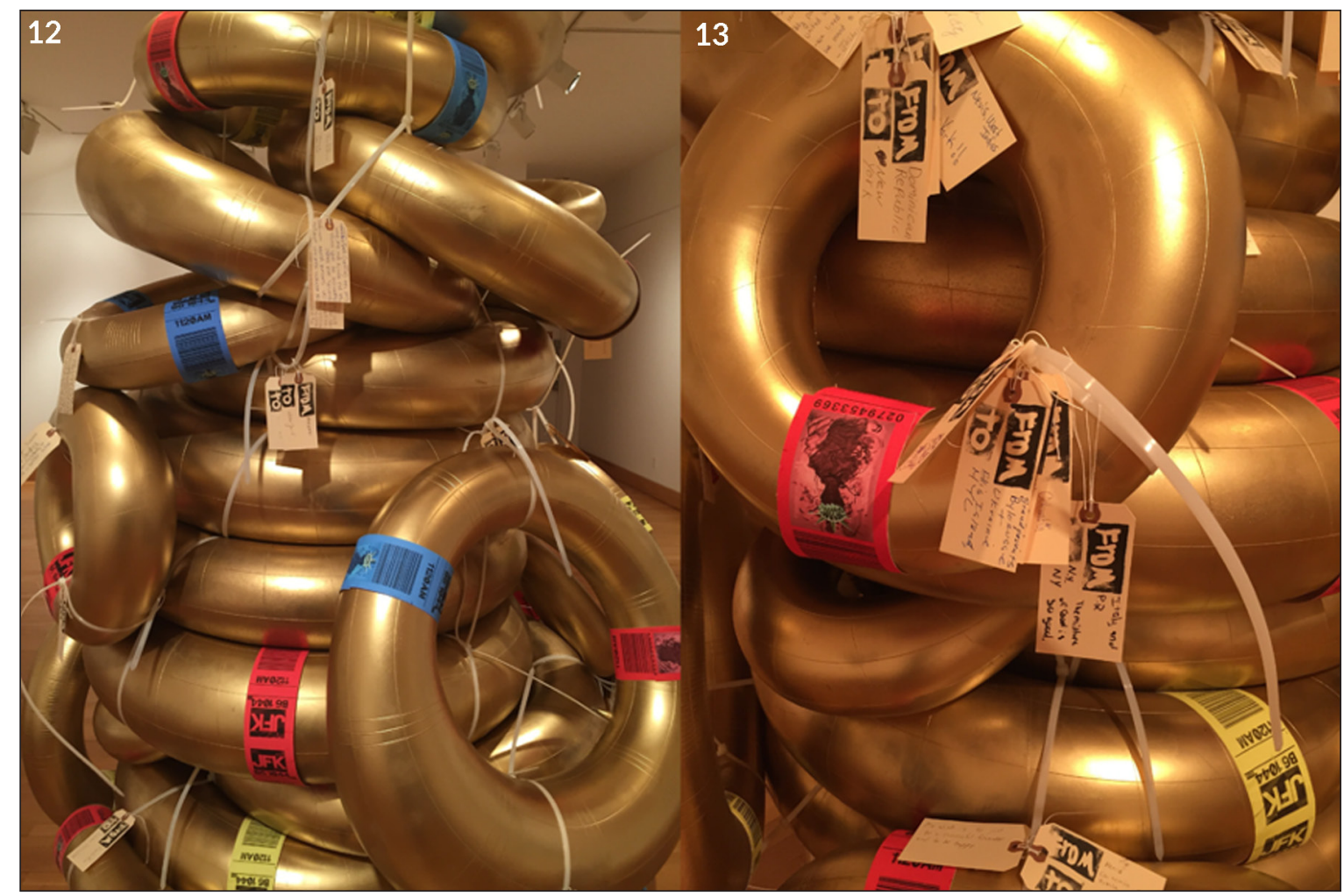

Figures 12 and 13: Cathedral/Catedral from: Garcia, Sherezade. 2015.

At the exhibit's opening, Garcia invited attendees to fill in suitcase ID tags with their place of origin and their destination and tie them to the sculpture (see Figures 12 and 13). The exhibit took place in New York City, where the Dominican-born Garcia is based. It calls attention to the city as the United States' iconic symbol of migratory freedom. Multiple interpretations are possible here. On the one hand, the inner tubes are a vessel, a cheap "boat" used to navigate when other safer means are unavailable. The inner tube can also serve as a life jacket albeit an often unsatisfactory one. By painting the inner tubes in gold, Garcia points to the migrant's desperate wish for a rickety inner tube to match the might of geographical distance and the power of the sea. The flimsiness of the inner tube can quickly render the migrant's "golden" dreams disastrous. An inner tube is an inadequate vessel with which to arrive at JFK. However, inner tubes are also often used for poolside leisure and with the ID tags transforming them into golden suitcases bound for continental airports, Garcia obliquely evokes the dreams of economic success with which migrants take to 
the seas and to the skies to reach "the land of opportunity." These golden tubes each stand for a migrant's dreams and hopes. Dreams of success are achieved the moment migrants arrive at a U.S. airport. Those left "back" in the homeland look on a migrant's arrival as a sign of having "made it:" a journey to aspire to and to try and emulate. The golden inner-tubes signify the fantasy of travel itself instead of the realities of life after migrants pick up their luggage and begin their new lives in earnest. The still inflated golden inner tubes with the airport tags attached signify a recent arrival or a "transient" nature not yet deflated by the realities of migrant life. By stacking the inner tubes and calling them Cathedral, Garcia again offers multiples meanings: the pyramid shape evokes a tomb, but as an altar the structure might also signify economic success as a religion. This is a religion for which "believers" are willing to sacrifice their lives. As a "ladder" of sorts, the tubes stacked together suggest that migrants rely on those who have come before them to climb an unstable, soft ladder. This unstable soft sculpture alludes to collective trauma, pain, death, but the golden hue also reminds the viewer of strength in numbers, as well as the protection and "sacredness" of belonging to a community. These latter features might be protective factors against the ravages of the sea and of life as a migrant.

At the end of the twentieth century, the Dominican artist Tony Capellán made a related statement in his artwork titled "Mar Caribe." For him, the sea is both a source of inspiration and the place where he often collects the found objects he uses to create his artworks (Scott 37). He is well-known for work that is concerned with social justice, environmental degradation, and migration and offers poignant commentary on the lives of the poor in the Dominican Republic, and by extension in the Caribbean and the "third-world." In Mar Caribe (Caribbean Sea, Figure 14), a particularly influential piece, Capellán arranges hundreds of blue and green flip-flops, each toe-strap outfitted with barbed wire, on a grid to mimic the surface of the Caribbean Sea. Capellán collected the worn flip-flops used for this compelling piece on beaches near the mouth of the Ozama River, a river that crosses the city of Santo Domingo, Dominican Republic. An adept beachcomber, he explains that when it rains, floodwaters sweep away objects and garbage belonging to people who live on the riverbanks, eventually disgorging these items at the mouth of the river. ${ }^{7}$ Mar Caribe, made just four years shy of the new millennium, has only increased in significance as a comment on the modern global condition.

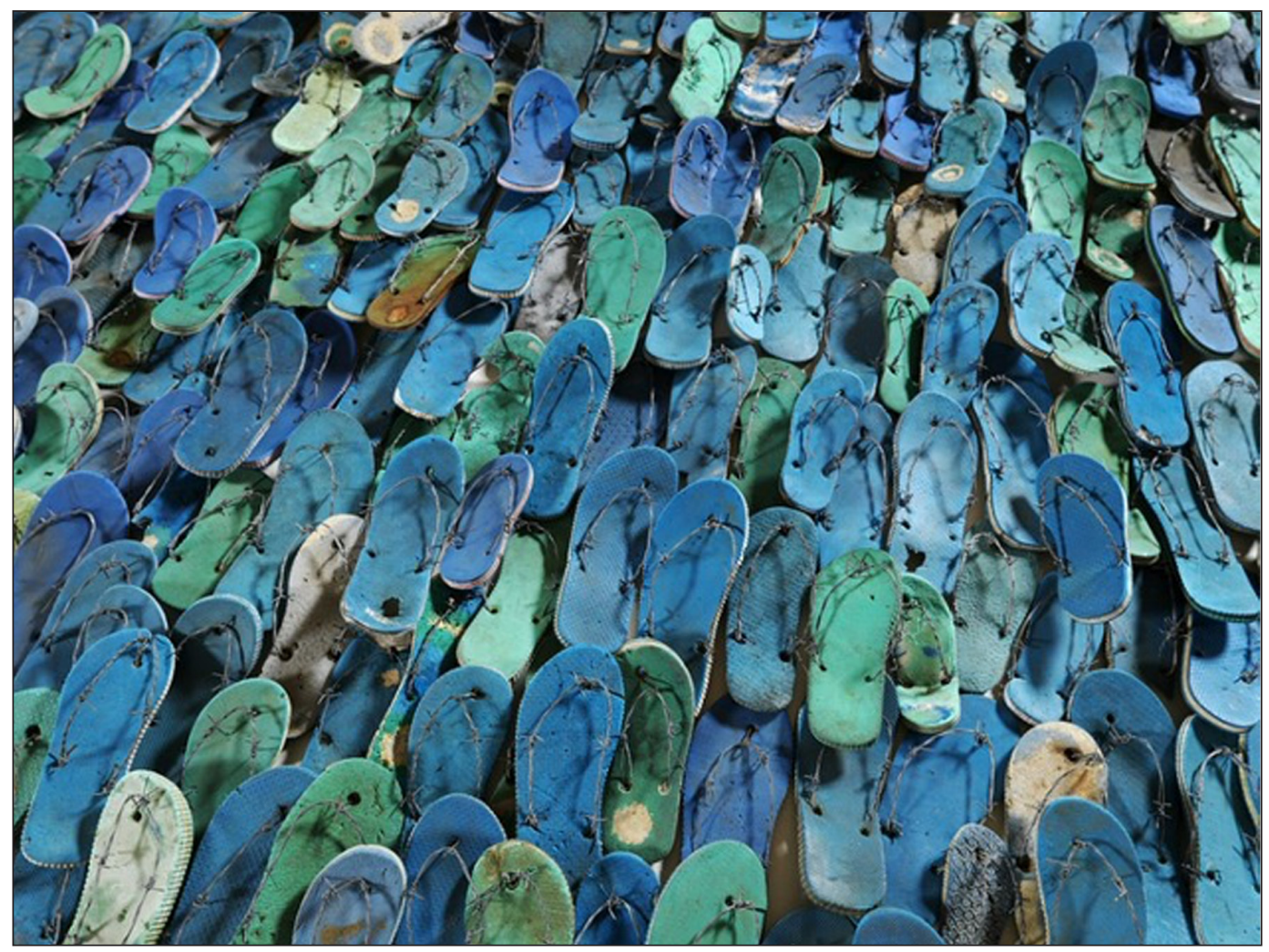

Figure 14: Mar Caribe from: Capellán, Tony. 1996.

\footnotetext{
See www.youtube.com/watch?v=zT5WnhJqx9A.
} 
With Mar Caribe, Capellán asks viewers to wonder about the kinds of lives the wearers of these sandals led. The viewer also confronts some of the difficult realities of modern life: poverty, waste management, pollution, and excess. Therein lies a double meaning in his deceptively simple but powerful use of the footwear of the poor, as well as of the leisure class to represent the contemporary global condition. In Wasted Lives, Zygmunt Bauman describes globalization as "the most prolific and least controlled 'production line' of human waste or wasted humans" (6). Bauman writes that:

[t]he global spread of the modern form of life set loose and put in motion enormous and constantly rising quantities of human beings bereaved of their heretofore adequate ways and means of survival in both the biological and social/cultural sense of that notion. (7)

In Bauman's framework, global modernity is an endemically "waste-producing form of life" that casts the poor as "superfluous bodies" no longer required for work, whose sheer numbers alone make them "redundant" and their very lives "wasted" (31; 40-42). Capellán places rubbish at the forefront by repurposing footwear to create the artwork thereby giving these discarded objects a second-life. Placed one beside the other the flip-flops, reminiscent of the sea, seem to go on forever calling attention to the "masses" of poor people living their human lives along the banks of the Ozama River. By altering the common rubber flipflop with barbed wire Capellán disrupts stereotypes about the Caribbean as a tropical paradise. Curator Sam Scott explains that:

the discarded objects Capellán collects to form his pieces are symptomatic of the economic uncertainty that plagues the Caribbean region. The pain of this condition is symbolized by the barbed wire. The poverty that underlines Mar Caribe has increasingly driven Caribbean people to take to the seas in a desperate migration to find better lives. (Scott 26)

In fact, the unidirectional placement of the flip-flops also suggests a collective movement and/or migration. In re-making the straps out of barbed-wire, Capellán underscores individuals besieged by historical pain and trauma who are prisoners of Historical conditions. The barbed-wire stands as the iconic symbol of places that are forbidden to some such as national borders as well as to the prisons to which trespassers are condemned. If each flip-flop represents an individual, much like Garcia's inner tubes, then, the individuals represented have been used, discarded, and forgotten and yet despite pain and trauma they "repurpose" and "re-imagine" their lives. These works also convey the message that collectively perhaps migrants can achieve more than any one individual.

In using disposable items to make their artworks, items such as the inner-tube and the flip-flop, both made for pool-side leisure, Garcia and Capellán signal that the "fantasies" of the global consumerist lifestyle do not exempt people based on socio-economic class and citizenship. Furthermore, they obliquely signal the global dependency on oil to make "affordable" but wasteful objects. Just as the flip- flop is discarded when the strap falls apart or on the day the tourists leave the resort, the thin plastic used to make inner-tubes is easily punctured. Both artists call attention to the transient usefulness of these objects. Much like an inner tube is easily deflated so are the dreams of the migrant when the realities of everyday life on the U.S. mainland or in Europe begin to set in. Similarly, flip-flops while convenient are not a shoe made for wearing on life's long haul and steep paths.

\section{Conditional Citizenship, Ambiguous Belongings, and Local Destruction}

As a U.S. territory, Puerto Rico occupies an ambiguous location between the Caribbean and the United States, its colonial condition often rendering its people impotent to decide the island's socio-political destiny. This is one of the reasons the Puerto Rican confrontation of the United States Navy over the 60-year (1941-2003) use of the island-municipality of Vieques as a bomb-testing site is a remarkable feat. The protests were triggered by the death of Vieques native David Sanes Rodriguez on April 19, 1999. Sanes Rodriguez, a civilian employed by the U.S. Navy, was working as a security guard during Marine Corps exercises when two 500pound bombs were dropped near his security post. His death gave rise to national and international protests and eventual departure in 2003 of the U.S. Navy from Vieques. During the years of protests, island artists rendered images of the plight of Vieques and of Puerto Rico against the mightier forces of the U.S. Navy.

The artistic duo made up by Puerto Rican Jennifer Allora and Cuban-born, Puerto Rico based Guillermo Calzadilla also took on the naval base's environmental degradation in their 2005 video titled Under Discussion (Figure 15). Allora and Calzadilla remarked: 
We arrived at Under Discussion through the metaphor of the discussion table. We were interested in the idea of the discussion table in liberal thought being the place where all different parties come together. So, we took the Vieques discussion table and we turned it upside down and made it into a boat. So, he drove along the historic fishing route, along the eastern lands of Vieques, where the local fishermen had first witnessed the destruction of the local ecosystem and mobilized [residents] against the ecological damage that also damaged their livelihood.

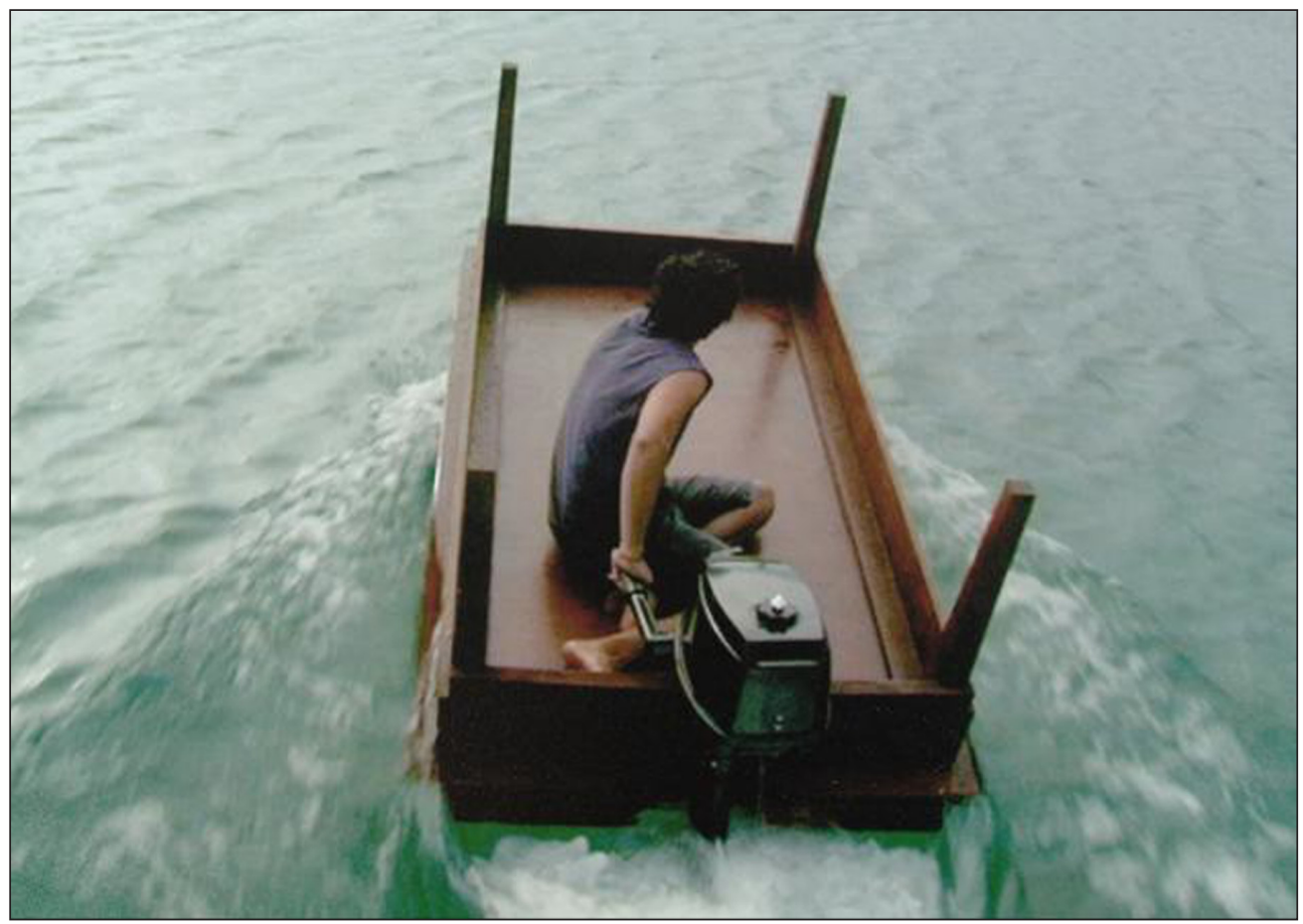

Figure 15: Under Discussion (still image) from: Allora, Jennifer and Guillermo Calzadilla. 2005.

In 1978 in Vieques local fishers, whose very livelihoods depended on the health of the ocean, were the first to protest the environmental degradation of their waters by the U.S. Navy (McCaffrey 77). The protagonist in Under Discussion is Diego de la Cruz, the son of a local fisherman who was part of the original protests against the Navy in the late 1970s (McKee, 2010). In selecting de la Cruz as the captain of the sea-worthy discussion table, the artists signal the inter-generational effects of both environmental devastation and marginality. Local fishers' and Vieques natives' exclusion from the political discussion table also translates into exclusion from the job market that has historically pushed Viequenses to migrate in search of better prospects.

Vieques remains a place of extraordinary natural beauty, so much so that it has become an eco-tourist destination advertised to the luxury market. But beneath the surface, contamination from unexploded bombs and artillery shells continue to devastate the health of the ocean and of the island's inhabitants. ${ }^{8}$ As Stanchich wrote on the tenth anniversary of the U.S. Navy withdrawal:

Vieques is belied by its grim social reality: severe environmental contamination; shockingly high cancer, unemployment and crime rates; and even more restricted access to its land than before the Navy ceasefire, with nearly 18,000 acres outside the bombing range now strictly controlled by the U.S. Fish and Wildlife Service of the Department of the Interior.

In some popular Western imaginaries, the sea appears to be a vast, infinite unexplored territory, free from ideologies and politics. But Allora and Calzadilla's piece poignantly reveals the opposite. In converting the

\footnotetext{
${ }^{8}$ See www.nydailynews.com/news/national/gonzalez-10-years-devastation-vieques-waters-article-1.1332740. See also Marie Cruz Soto's Inhabiting Island Nena, 1514-2003: Island Narrations, Imperial Dramas and Vieques, Puerto Rico. Unpublished Doctoral Dissertation. University of Michigan, 2008.
} 
liberal-democratic discussion table into a vessel, they have marked the sea-which belongs to the local fishers as much as to the state-as a significant territory of competing interests.

Invisible lines and demarcations crisscross the sea like a grid, marking territorial claims as well as local and international political struggles. Far from being just a source of freedom or leisure, the waters surrounding the island of Vieques conceal catastrophic levels of contamination, the legacy of modern imperial politics, and the mismanagement of military waste. This legacy cannot be hidden deep in the ocean because island residents are confronted with the scars, both embodied and environmental, every day.

\section{The Human Sea}

The conceptual documentary photographer Nadia Huggins, who lives in St. Vincent and the Grenadines, engages with the sea as subject in a profoundly humanizing way. In fact, it is precisely this humanizing quality that makes her images appear at once familiar, but enigmatic. Her keen engagement with the sea as object, medium, and ecosystem offers viewers a singular "look." Instead of representing the sea as a distant body, Huggins enters the sea and locates her body inside the very medium she contemplates. In this way, she renders the sea as womb- like at once protective but not entirely knowable. Huggins does not offer the sea as mere metaphor but instead it is transformed into a site for immersion; the sea is experienced and understood through the body, and in doing so, Huggins removes from the artwork the sea as a site of desperation and migration's drama. In this artwork, the sea is a site of/for "rejoicing" and offers a discursive vein into refreshing ways of understanding Caribbean artists' relationship to the sea to reorient how they act upon territorial and aquatic lifeworlds and see themselves as active agents of their own narratives. In the evocative series titled "Transformations," ${ }^{9}$ Huggins juxtaposes various parts of her body with marine organisms. Together each image-pair creates a hybrid portrait of human-marine life. Seeing Huggins' neck and head fully submerged in the water and paired against a diadema antillarum (sea urchin) offers dense commentary on the multiple worlds shared among living beings, on the rights and value of human versus animal life, and on the fragility of biological life (see Figure 16).

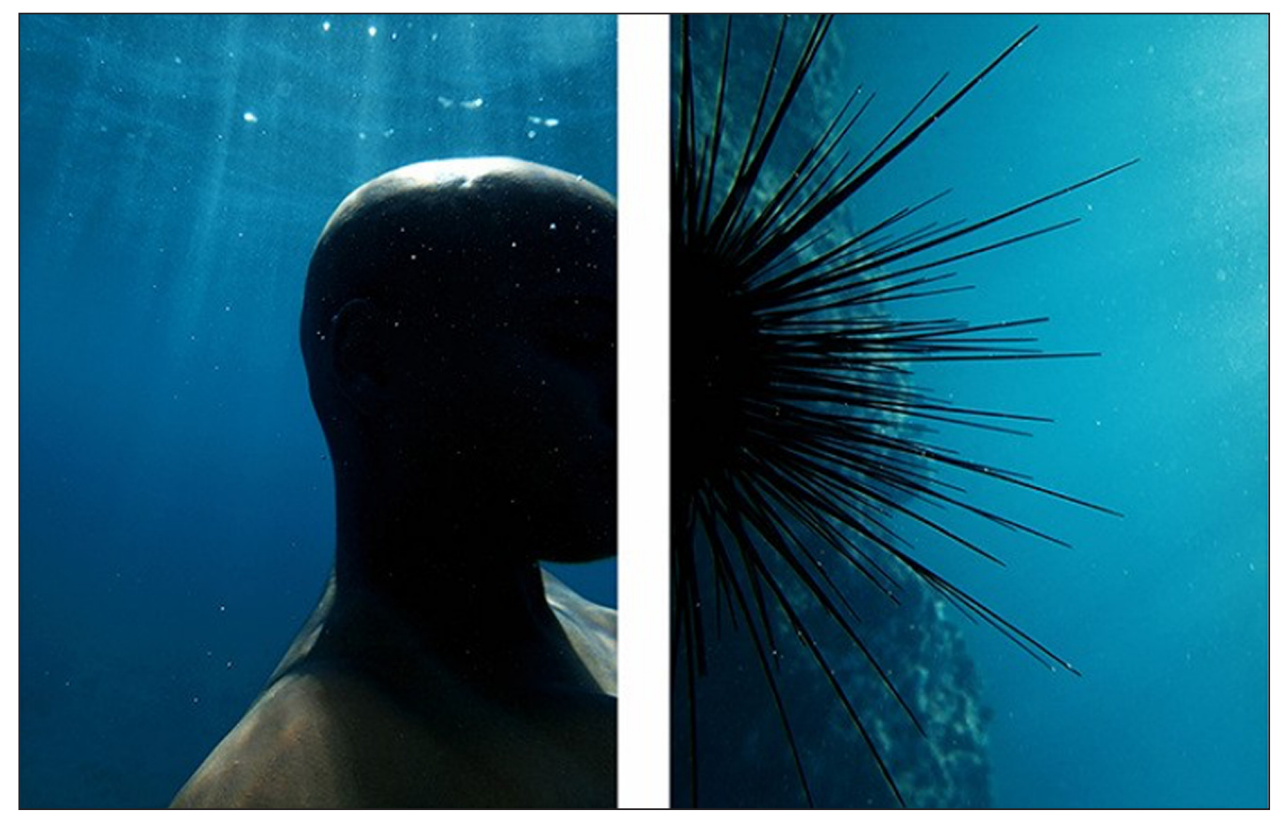

Figure 16: “Transformation” Series (still image) from: Huggins, Nadia. 2015.

The juxtaposition against the black sea urchin is particularly poignant because its long spines, which warn of danger, offers an alien face to the artist or perhaps the upper body of the artist offers an alien body to the urchin? In any case, the black urchin (diadema antillarum), is the subject of a great mystery because between 1983 and 1984, besieged by a virulent disease, its population began to die off enmasse experiencing "one of the most devastating mortalities ever recorded in a marine animal" (Miller et al. 181). Once healthy and abundant throughout the Caribbean, the species has been making a slow comeback (Engman).

\footnotetext{
${ }^{9}$ See www.nadiahuggins.com/Transformations-1.
} 
Huggins, who is in her words "a woman who identifies as other," evokes the alien-like otherness of the black urchin and this begs the question of whether these "others" have the right to life, to clean environments, and healthy ecosystems? Or if by virtue of their profound otherness they are non-beings whose lives are inconsequential? In a statement about this series, Huggins writes that she is concerned with what lies beyond the surface and the dictum “just because you can't see something it doesn't mean it isn't there." For this reason, she enters the ocean, transforming her body and self simultaneously into medium and icon.

By going "beyond the surface" and entering the sea Huggins underscores the human power to enter "alien" non-human environments and to cohabitate within those environments (however briefly). In this way, she is also enacting an uneven power relationship with the organisms she encounters accentuating that these organisms cannot travel across environments, the ocean is their only home. Is the fact that humans use technology to adapt and make lives in multiple environments one reason for the disregard and relentless destruction of eco-systems? Beyond the surface are worlds and "Transformations" powerfully reminding viewers that these worlds are infinite. There are the worlds within the artist: psychological states, the embodiment of emotions and of social-cultural markers. Then there are the worlds within the marine environment, each organism carrying a world within it.

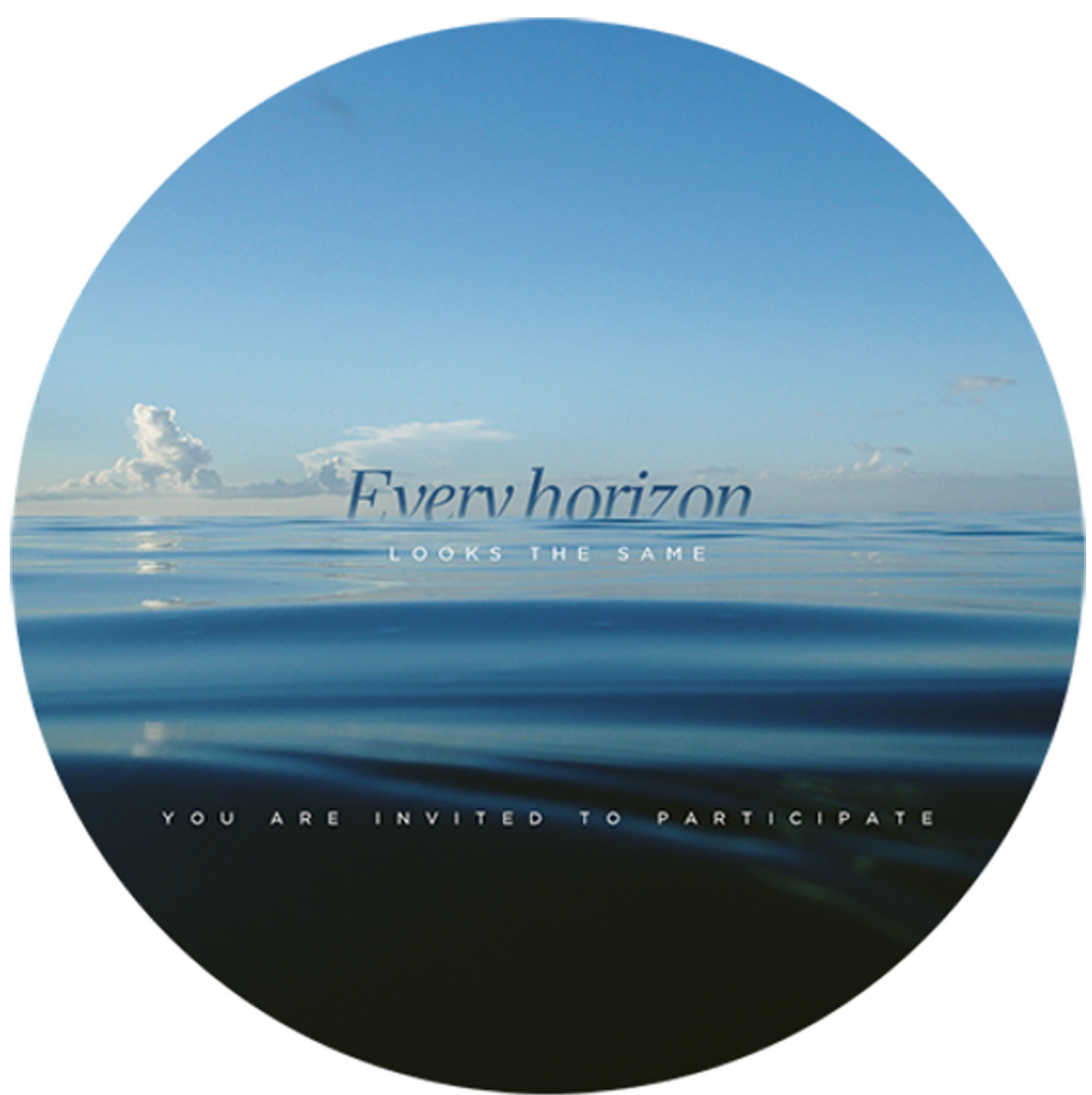

Figure 17: "Every horizon looks the same" from: Huggins, Nadia. 2016.

In the participatory project "Every horizon looks the same," ${ }^{10}$ Huggins invites participants to submit photographs of ocean horizons. While the contributor of each photograph remains anonymous the geographic location of each image is tagged.

Huggins explains that

the horizon line, there is a story of our shared history, our future, exploration, possibilities, disappointments, fear and hope. I wish to build an archive of ocean horizons for the purpose of mapping a collective human experience.

\footnotetext{
${ }^{10}$ See www.nadiahuggins.com/Every-horizon-looks-the-same.
} 
With this endeavor, the artist seeks to underscore our common preoccupation with the sea as that shared body worthy of imaging. In fact, Huggins explains that this project emanated from her observation that the ocean horizon is one of the most reproduced images in social media. No matter where we live humans seem to be collectively awed by the ocean. In this participatory work, Huggins and the anonymous collaborators depict the ocean at eye/I level and at a distance. Distance is key in the imaging of the sea's vast and mighty form conveying the sea as a world apart and as mysterium tremendum et fascinans. Perhaps one reason for the popularity of the imaging of sea horizons in social media-the juxtaposition of our shared sea and sky-is to serve as reminder of the numinous experience?

\section{Coda}

In 1943, Cuban author Virgilio Piñera wrote: "La maldita circunstancia del agua por todas partes..." this is the well-known first line from his poem titled, "La isla en Peso." In it, Piñera poignantly addresses the "damning" circumstances to which island dwellers seem pre-destined: the burden and confinement resulting by being surrounded by water. Throughout this article I show that the artists examined here challenge the master tropes about the Caribbean under which their work tends to be subsumed, or as Piñera would describe, "condemned" by their circumstances. The systematic exploration of contemporary Caribbean artists' depictions of human-sea interactions at the beginning of the twenty-first century reveals that they imagine the sea as a profoundly human territory. Political, economic, and cultural claims and struggles are mapped onto the sea; the sea is neither a neutral nor an empty zone. One way in which these artists counter the seemingly diffuse and spectral global forces that cause islanders to risk their lives at sea or to lose their livelihoods to disastrous environmental degradation is to tell highly localized "small histories," and personal stories. In doing so, they call attention not only to local issues, but to the ways in which these are global stories that affect everyone (even though the degree to which a person is affected depends on their national origin and also on their social-economic class). By using the sea to articulate messages, these artists draw on metaphors of connection, distance, inequality, and "global" reality. Waste, pollution, environmental degradation, poverty, perilous sea crossings, and dislocation are increasingly trans-hemispheric human problems.

Through the use of complex metaphors and creative storytelling, these artists suggest that in the twenty-first century the globe can be understood as a "societal area' since its component societies probably share many ... social-structural features" (Mintz 914-915). To be clear, in the global "financial era" these shared social-structural features include deleterious features such as environmental degradation, increasing inequality and poverty, and a successive wave of "migrant crises," the direct result of militarization and war, economic globalization, climate change, drought, and famine. The paradoxical perception that their island-homes are tropical paradises whose people are lagging behind "the times," excessive and redundant to the current "high-tech" economic condition has long been a perception endured by Caribbean natives.

The artists I discuss here and whose work is recognized as among the most visible of Caribbean visual arts effectively seize upon their own paradoxical realities as Caribbeans and cosmopolitans, Caribbean nationals, migrants and U.S. citizens, critical but still dependent on the "global" art market as a source of validation and income. The success of their artwork is the result of the fact that in visualizing local realities, they increasingly visualize the global condition. The Caribbean's history as a laboratory of the "modern" and the "globalized" has undoubtedly offered these artists a vantage point from which to launch their "localized" interventions. These artistic interventions often speak about and speak back to raging forces increasingly turning large segments of humanity into excessive and redundant migrants, border-crossers, trans-nationals, and victims of environmental ruination, decay, and disaster.

\section{Acknowledgements}

I presented an early version of this article in 2015's Edmund S. and Nathalie Rumowicz Endowed Seminar and Lecture Series in Literature and the Sea and The College of Arts and Sciences, University of Rhode Island. I am grateful to Dr. Martha Elena Rojas for the invitation to present this work.

I am thankful for the generous developmental suggestions I received from Anthurium reviewers. I owe a debt of gratitude to Miguel Antony Vasquez for ushering this article through the publication process.

\section{Competing Interests}

The author has no competing interests to declare. 


\section{References}

Agamben, Giorgio. Homo Sacer: Sovereign Power and Bare Life. Stanford UP, 1998.

Allora \& Calzadilla. "Under Discussion" and "Vieques." Art21, 2007, www.art21.org/texts/allora-calzadilla/ interview-allora-calzadilla-under-discussion-and-vieques.

Basch, Linda, Nina Glick Schiller, and Cristina Blanc-Szanton. Nations Unbound: Transnational Projects, Postcolonial Predicaments, and Deterritorialized Nation-States. Gordon and Breach, 1994.

Bassi, Ernesto. An Aqueous Territory: Sailor Geographies and New Granadas Transimperial Greater Caribbean. Duke UP, 2017.

Bauman, Zygmunt. Wasted Lives: Modernity and its Outcasts. Polity, 2003.

Bauman, Zygmunt. "Wasted Lives: Modernity and its Outcasts." Breaching Borders: Art, Migrants and the Metaphor of Waste, edited by Juliet Steyn and Nadja Stamselberg, Tauris \& Co, 2014, pp. 1-25.

Benítez-Rojo, Antonio. The Repeating Island: The Caribbean and the Postmodern Perspective. Duke UP, 1992.

---. "The New Atlantis: The Ultimate Caribbean Archipelago." Displacements and Transformations, edited by Lizabeth Paravisini-Gebert and Ivette Romero-Cesareo, UP of Florida, 2008, pp. 215-224.

Berg, Ulla. "Scherezade García: Sabana de la Mar, Salvation Action." NYU Institute of Performance and Politics, 2006, www.hemi.nyu.edu/journal/3.2/artistspresentation/scherezadegarcia/esp/index.html.

Bonilla, Yarimar and Max Hantel. "Visualizing Sovereignty: Cartographic Queries for the Digital Age." SX Archipelagos, 2016, smallaxe.net/sxarchipelagos/issue01/bonilla-visualizing.html\#fn:5.

Bourriaud, Nicolas. Relational Aesthetics. Les Presses du Reél, 2002.

Carnegie, Charles V. Postnationalism Prefigured: Caribbean Borderlands. Rutgers UP, 2002.

Chavez, Leo R. The Latino Threat: Constructing Immigrants, Citizens, and the Nation. Stanford UP, 2008.

Clifford, James. Routes: Travel and Translation in the Late Twentieth Century. Harvard UP, 1997.

Crichlow, Michaeline A. "Making Waves: (Dis)Placements, Entanglements, Mo(ve)ments." The Global South, vol. 6, no. 1, 2012, pp. 14-137.

Curet, Antonio L. and Mark W. Hauser. "Introduction: Migration, Seafaring, and Cultural Contact in the Caribbean." Islands at the Crossroads: Migrations, Seafaring, and Interaction in the Caribbean, edited by L. Antonio Curet and Mark W. Hauser, U of Alabama P, 2011, pp. 1-12.

D'Arcy, Paul. The People of the Sea: Environment, Identity, and History in Oceania. U of Hawai'i P, 2006.

DeLanda, Manuel. A Thousand Years of Non-Linear History. Zone Books, 1997.

Duany, Jorge. Blurred Borders: Transnational Migration Between the Hispanic Caribbean and the United States. U of North Carolina P, 2011.

Engman, James. "Mass Mortality in Diadema Antillarum (Echinodermata:Echinoidea): A Large Scale Natura." JRS Science, 2002, jrscience.wcp.muohio.edu/FieldCourses00/PapersMarineEcologyArticles/ MassMortalityinDiademaant.html.

García, Scherezade. Aguas Libres/Waters of Freedom. The Art Gallery at the College of Staten Island and personal communication, 18 May, 2015.

Gardner, Anthony and Charles Green. "When Art Migrates: Biennales and Itinerancy." Breaching Borders: Art, Migrants and the Metaphor of Waste, edited by Juliet Steyn and Nadja Stamselberg, Tauris \& Co, 2014, pp. 139-163.

Gilroy, Paul. Small Acts: Thoughts on the Politics of Black Cultures. Serpent's Tail, 1993.

Glissant, Édouard. Caribbean Discourse: Selected Essays. U P of Virginia, 1989.

Graziano, Frank. Undocumented Dominican Migration. U of Texas P, 2013.

Hannerz, Ulf. "The Withering Away of the Nation? An Afterword" Ethnos, vol. 58, no. 3-4, 1993, pp. 377-391.

Harris, Wilson E. "History, Fable and Myth in The Caribbean and Guianas." Caribbean Quarterly, vol. 54, no. (1/2), 1995, pp. 5-38.

Hooks, bell. Art on My Mind: Visual Politics. The New Press, 1995.

Hyde, Lewis. Trickster Makes this World: Mischief, Myth and Art. North Point Press, 1998.

Küchler, Suzanne and Walter Melion, editors. Images of Memory: On Remembering and Representation. Smithsonian Institution Press, 1991.

Laughlin, Nicholas. "Working Notes: On Christopher Cozier's Tropical Night Drawings." Choosing My Confessions, 2007, www.nicholaslaughlin.net/tropical-night-working-notes.html.

Martínez, Samuel. "Identities at the Dominican and Puerto Rican International Migrant Crossroads." In Marginal Migrations: The Circulation of Cultures within the Caribbean, edited by Shalini Puri, MacMillan Caribbean, 2007, pp. 141-164.

Martínez-San Miguel, Yolanda. "De Ilegales e Indocumentados: Representaciones Culturales de la Migración Dominicana en Puerto Rico." Revista de Ciencias Sociales, 1998, vol. 4, pp. 147-173. 
-_-. Caribe Two-Ways: Cultura de la Migración en el Caribe Insular Hispánico. Ediciones Callejón, 2003.

Márquez, John D. "Latinos as the "Living Dead": Raciality, Expendability, and Border Militarization." Latino Studies, 2012, no. 10, pp. 473-498.

McCaffrey, Katherine. Military Power and Popular Protests. The U.S. Navy in Vieques, Puerto Rico. Rutgers UP, 2002.

McKee, Yates. "Wake, Vestige, Survival: Sustainability and the Politics of Trace in Allora and Calzadilla's Land Mark." October 133, 2010, pp. 20-48.

Miller, R. J., A. J. Adams, N. B. Ogden, J. C. Ogden, J. P. Ebersole. “Diadema antillarum 17 years after mass mortality: is recovering beginning on St. Croix?" Coral Reels, 2003, vol. 22, no. 2, pp. 181-187.

Mintz, Sydney. The Caribbean as a socio-cultural area." Cahiers d'Histoire Mondiale, 1966, no. 4, pp. 912-37.

---. Caribbean Transformations. Aldine Publishing, 1974.

-_-. "Enduring Substances, Trying Theories: The Caribbean Region as Oikoumene." Journal of the Royal Anthropological Institute, 1996, vol. 2, no. 2, pp. 289-311.

-_-. "The Localization of Anthropological Practice: From Area Studies to Transnationalism." Critique of Anthropology, 1998, vol. 18, no. 2, pp. 117-33.

Mitchell, W.J.T. What do Pictures Want? The Lives and Loves of Images. U of Chicago P, 2005.

Mohammed, Patricia. Imaging The Caribbean: Culture and Visual Translation. McMillan, 2009.

Mol, Angus A. A. The Connected Caribbean: A Socio-material Network Approach to Patterns of Homogeneity and Diversity in the Pre-Colonial Period. Sidestone Press, 2014.

Morales, René. "Caribbean Art and the Myth of Insularity." Island Thresholds: Contemporary Art from the Caribbean, Peabody Essex Museum, 2005, pp. 8-13.

Mörtenböck, Peter. "Network Economies of Waste." Breaching Borders: Art, Migrants and the Metaphor of Waste, edited by Juliet Steyn and Nadja Stamselberg, Tauris \& Co, 2014, pp. 217-238.

Mosaka, Tumelo. Infinite Island: Contemporary Caribbean Art. Brooklyn Museum in Association with Philip Wilson Publishers, 2007.

Oboler, Suzanne and Deena J. González. "Border Art." The Oxford Encyclopedia of Latinos and Latinas in the United States, Oxford UP, 2005.

Paravisini-Gebert, Lizabeth and Ivette Romero-Cesareo. “The 'Children of the Sea': Uncovering Images of the Botpippel Experience in Caribbean Art and Literature." Displacements and Transformations in Caribbean Cultures, edited by Lizabeth Paravisini-Gebert and Martha Daisy Kelehan, 2008, UP of Florida, pp. 127-161.

Patterson, Orlando. "Migration in Caribbean Societies: Socioeconomic and Symbolic Resource." Human Migration: Patterns and Policies, edited by W. McNeill and R. Adams, Indiana UP, 1978, pp. 106-145.

Pratt, Mary Louise. Fieldwork in Common Places. In Writing Culture: The Peotics and Politics of Ethnography, edited by James Clifford and George Marcus, U of California P, 1986, pp. 27-50.

Ruffins, Fath Davis. "Mythos, Memory, and History: African American Preservation Efforts, 1820-1990." In Exhibiting Cultures: The Poetics and Politics of Museum Display, edited by Ivan Karp and Steven Lavine, Smithsonian Institution Press, 1992, pp. 506-611.

Scott, Sam. "Contemporary Thresholds in the Art of the Sea." In Island Thresholds: Contemporary Art from the Caribbean, Peabody Essex Museum, 2005, pp. 16-34.

Stanchich, Maritza. "2013 Ten Years After Ousting US Navy, Vieques Confronts Contamination." Huffington Post. 6 Dec 2017. www.huffingtonpost.com/maritza-stanchich-phd/ten-years-after-oustingu_b_3243449.html.

Subero, Jose. Personal communication. Received by Hilda Lloréns. 13 August 2015.

Trouillot, Michel-Rolph. "Anthropology and the Savage Slot: The Poetics and Politics of Otherness." In Recapturing Anthropology: Working in the Present, edited by Richard G. Fox, School of American Research Press, 1991, pp. 17-44.

--_. Silencing the Past: Power and the Production of History. Beacon Press, 1995.

-_- "Culture on the Edges: Creolization in the Plantation Context." Special Issue: "Who/What is Creole?" edited by A. James Arnold, Plantation Society in the Americas 5(1): 8-28, 1998.

-_-. "The Otherwise Modern: Caribbean Lessons from the Savage Slot." Critically Modern: Alternatives, Alterities, Anthropologies, edited by Bruce M. Knauft, Indiana UP, 2002, pp. 220-237.

Turner, Victor. The Ritual Process. Aldine, 1969.

Wainwright, Leon. Timed Out: Art and the Transnational Caribbean. Manchester UP, 2011.

Walcott, Derek. Collected Poems: 1948-1984. Straus \& Giroux, 1986. 
Walsh, Kevin. The Representation of the Past: Museums and Heritage in the Post-Modern World. Routledge, 1992.

Weber, Leanne and Sharon Pickering. Globalization and Borders: Death at the Global Frontier. Palgrave MacMillan, 2011.

Wolf, Eric. Europe and the People Without History. U of California P, 1982.

Wood, Yolanda. Islas del Caribe: Naturaleza-Arte-Sociedad. La Habana: Editorial, 2012.

How to cite this article: Lloréns, H 2021 A Passion for the Sea: Human-Sea Interactions in Contemporary Caribbean Art. Anthurium, 17(1): 8, 1-20. DOl: https://doi.org/10.33596/anth.358

Published: 01 September 2021

Copyright: ( 2021 The Author(s). This is an open-access article distributed under the terms of the Creative Commons Attribution 4.0 International License (CC-BY 4.0), which permits unrestricted use, distribution, and reproduction in any medium, provided the original author and source are credited. See http://creativecommons.org/licenses/by/4.0/. 